\title{
Tumor Necrosis Factor- $\alpha$ and Phorbol 12-Myristate 13-Acetate Differentially Modulate Cytotoxic Effect of Nitric Oxide Generated by Serum Deprivation in Neuronal PC12 Cells
}

\author{
Kwang Chul Chung, Jae Hyun Park, Chul Hoon Kim, and Young Soo Ahn \\ Department of Pharmacology and Brain Research Institute, Yonsei University College of Medicine, Seoul, Korea
}

\begin{abstract}
Nitric oxide (NO) is a signaling molecule that mediates several physiological processes in a range of cell and tissue types. Here we investigated the effect of serum deprivation in the absence or presence of phorbol 12-myristate 13-acetate (PMA) or tumor necrosis factor- $\alpha$ (TNF $\alpha$ ) on cell viability, NO formation, inducible NO synthase (iNOS) induction, and activation of mitogen-activated protein kinase in neuronal PC12 cells. Within $24 \mathrm{~h}$ of serum deprivation, apoptosis occurred in up to 65$70 \%$ of the cells, and significant levels of NO were generated. When PMA was added in serum-free medium, NO formation and cell death were decreased. In contrast, addition of TNF $\alpha$ in serum-free medium increased the levels of $\mathrm{NO}$ formation and apoptosis compared with those in serum-deprived cells. We have demonstrated that differential generation of NO levels by PMA or TNF $\alpha$ under conditions of serum deprivation is mediated by the same pattern of iNOS induction. NO formation via iNOS induction resulted in the activation of $\mathrm{c}$-Jun $\mathrm{N}$-terminal kinase (JNK) but not extracellular signal-regulated kinase. From this study it is suggested that the differential formation of cytotoxic $\mathrm{NO}$ by serum deprivation plus PMA or TNF $\alpha$ is primarily mediated by the induction of iNOS enzymes in neuronal PC12 cells and that its action is mediated by the activation of JNK. Key Words: Serum deprivation-Nitric oxide-Phorbol 12-myristate 13-acetate-Tumor necrosis factor- $\alpha$-Inducible nitric oxide synthase-c-Jun N-terminal kinase.

J. Neurochem. 72, 1482-1488 (1999).
\end{abstract}

Neuronal cell death occurs not only during development but also as a consequence of acute traumatic events or chronic degenerative disorders that disturb cellular homeostasis, such as trauma, ischemia, and aging (Oppenheim, 1991). Like most if not all animal cells, neuronal cells contain an endogenous suicide program that is activated when specific cell numbers are to be reduced or in response to genotoxic signals. Cell death can be triggered by various intrinsic and extrinsic signals (Wyllie, 1993). Oxidative stress is involved in the induction of neuronal death during neuron degeneration (Coyle and Puttfarcken, 1993). Nitric oxide (NO) plays a complex role in regulating cell viability. In primary cultured cor- tical neurons, NO mediated glutamate toxicity (Dawson et al., 1991), and in bovine aortic endothelial cells it mediated the cytotoxicity of inflammatory cytokines such as tumor necrosis factor- $\alpha(\mathrm{TNF} \alpha)$ (Estrada et al., 1992). In contrast, under certain circumstances, NO generation prevented apoptosis in various cell types (Nicotera et al., 1997). Thus, the biological activities of NO appear to be mediated by multiple effectors, and the effect of NO on cell viability is dependent on its concentration, cellular redox state, and the particular cell type.

NO is endogenously produced by NO synthase (NOS; EC 1.14.13.39). Molecular cloning and sequencing analyses revealed the existence of at least three main types of NOS isoforms: endothelial NOS, neuronal NOS, and inducible NOS (iNOS). Like NO, the regulatory effect of iNOS on cell function is also controversial, particularly the effect on cell viability.

$\mathrm{TNF} \alpha$ is a multifunctional cytokine involved in inflammation, cell growth, and apoptosis (Wallach, 1997). The pleiotropic effects of TNF $\alpha$ are mediated through cell surface receptors. Some of the known signal transduction pathways of $\mathrm{TNF} \alpha$ include coupling to G proteins, activation of phospholipase $\mathrm{A}_{2}$, calcium mobilization, and ceramide production. In addition to the above messengers, reactive oxygen species have recently been recognized as acting as signaling intermediates for cytokines, including TNF $\alpha$ (Aggarwal and Natarajan, 1996). Although the activation of protein kinase C (PKC) by

Received August 18, 1998; revised manuscript received December 3 , 1998; accepted December 8, 1998.

Address correspondence and reprint requests to Dr. K. C. Chung at Department of Pharmacology, Yonsei University College of Medicine, Seoul 120-752, Korea.

Abbreviations used: AG, aminoguanidine; DMEM, Dulbecco's modified Eagle's medium; ERK, extracellular signal-regulated kinase; GST, glutathione $S$-transferase; iNOS, inducible nitric oxide synthase; JNK, c-Jun N-terminal kinase; LDH, lactate dehydrogenase; MAP, mitogen-activated protein; NO, nitric oxide; NOS, nitric oxide synthase; PKC, protein kinase C; PMA, phorbol 12-myristate 13-acetate; SNAP, $S$-nitroso- $N$-acetylpenicillamine; SNP, sodium nitroprusside; $\mathrm{TNF} \alpha$, tumor necrosis factor- $\alpha$. 
phorbol 12-myristate 13-acetate (PMA) is generally thought to induce cell death mediated by increased production of NO, there are many contrasting reports in many different systems.

The mitogen-activated protein (MAP) kinase signaling pathway mediates various biological events, including mitogenesis, differentiation, and cell death. The mammalian MAP kinase family includes extracellular signalregulated kinase (ERK), c-Jun N-terminal kinase (JNK), and p38 kinase (Robinson and Cobb, 1997). ERKs are activated in response to mitogens such as peptide growth factors. JNK is activated in response to various cellular stresses, including DNA damage, heat shock, or proinflammatory cytokines, such as TNF $\alpha$ and interleukin $1-\beta$. Similar to JNK, p38 kinase is also activated in response to various stresses. It was recently shown that TNF $\alpha$ induces JNK activity and c-Jun expression (Lo et al., 1996) and that NO stimulates JNK activity (Kim et al., 1997).

Rat pheochromocytoma (PC12) cells constitute a useful model for studying the mechanism of neuronal cell death and its prevention. Serum deprivation-induced cell death is an in vitro model of massive neuronal death during development (Rukenstein et al., 1991). In the present study, we investigated the effect of serum deprivation in the presence of PMA or TNF $\alpha$ on NO formation, cell viability, iNOS induction, and the activation of the MAP kinase pathway in PC12 cells. The effect of NO on cell death and the MAP kinase signaling pathways may elucidate a molecular mechanism by which $\mathrm{NO}$ exerts its physiological functions in target cells.

\section{EXPERIMENTAL PROCEDURES}

\section{Cell culture}

PC12 cells were cultured in Dulbecco's modified Eagle's medium (DMEM) supplemented with 5\% heat-inactivated fetal bovine serum and 5\% horse serum. To assess cell viability after serum deprivation and treatment with $\mathrm{PMA}, \mathrm{TNF} \alpha$, NO donor, or iNOS inhibitor, PC12 cells were plated on 24-well $\left(2-\mathrm{cm}^{2}\right)$ plates. To provide a serum-free environment, the cells were washed two times with serum-free DMEM and then placed in fresh serum-free medium for the indicated time. Protein concentrations were determined using a protein assay kit from Bio-Rad (Hercules, CA, U.S.A.) as described in the manufacturer's protocol.

\section{Cell death assessment}

Cell death was quantified either by the trypan blue staining method or by measuring the amount of lactate dehydrogenase (LDH) released from membrane-damaged cells. To count trypan blue-excluding viable cells, cells were removed from the culture plate by trypsin, and the supernatant was removed by brief centrifugation $(1,000 g$ for $5 \mathrm{~min})$. The cell pellets were resuspended in $100 \mu \mathrm{l}$ of phosphate-buffered saline and $100 \mu \mathrm{l}$ of trypan blue solution $(0.8 \%$ trypan blue, $0.81 \% \mathrm{NaCl}$, and $0.06 \% \mathrm{~K}_{2} \mathrm{HPO}_{4}$ ). Live cells were counted using a hemacytometer. $\mathrm{LDH}$ assessment was performed to measure the amount of LDH released into media for $24 \mathrm{~h}$ from serum-deprived or drug-treated cells, relative to total LDH content measured after cells were completely destroyed by $1 \%$ Triton X-100. LDH released from cells was reacted with pyruvic acid and $\beta$-nico- tinamide adenine dinucleotide (reduced form), and the reaction was measured spectrophotometrically at $340 \mathrm{~nm}$.

\section{Analysis of annexin V-FITC binding}

Approximately $5 \times 10^{5}$ cells per experimental condition were harvested, washed with phosphate-buffered saline, and resuspended in $150 \mu \mathrm{l}$ of HEPES buffer [10 $\mathrm{m} M$ sodium HEPES (pH 7.4), $150 \mathrm{~m} M \mathrm{NaCl}, 5 \mathrm{~m} M \mathrm{KCl}, 1 \mathrm{mM} \mathrm{MgCl}{ }_{2}$, and $1.8 \mathrm{mM} \mathrm{CaCl}{ }_{2}$ ]. Cells were incubated for $15 \mathrm{~min}$ at $37^{\circ} \mathrm{C}$ in the presence of $2 \mu \mathrm{g} / \mathrm{ml}$ annexin V-FITC (Boehringer Mannheim), washed twice with HEPES buffer, and resuspended with $400 \mu \mathrm{l}$ of the same buffer. To distinguish the cells that had lost membrane integrity, propidium iodide was added to a final concentration of $50 \mu \mathrm{g} / \mathrm{ml}$ before flow cytometry analysis.

\section{DNA fragmentation}

Approximately $2 \times 10^{6}$ cells from each experimental condition were lysed by incubation in $10 \mathrm{~m} M$ Tris- $\mathrm{HCl}$ (pH 7.5), 1 $\mathrm{m} M$ EDTA, and $0.2 \%$ Triton X-100 for 30 min at $4{ }^{\circ} \mathrm{C}$. Cell organelles were removed by centrifugation at $12,000 \mathrm{~g}$ for 20 min, and the fragmented DNA present in the supernatant was ethanol-precipitated and resuspended in $50 \mu \mathrm{l}$ of $10 \mathrm{~m} M$ Tris$\mathrm{HCl}(\mathrm{pH} 8.0)$ and $1 \mathrm{mM}$ EDTA. Aliquots $(10 \mu \mathrm{l})$ were analyzed by electrophoresis on $1.2 \%$ agarose gels.

\section{Nitrite content measurement}

Nitrite was quantified by the Griess reaction (Follett and Ratcliff, 1963). $\mathrm{HCl}(4 M)$ was added to the supernatant for 10 min, and then $2 \mathrm{mg} / \mathrm{ml}$ sulfanilic acid and $1 \mathrm{mg} / \mathrm{ml} \mathrm{N}$-(1naphthyl)ethylenediamine were added. After incubation for 30 min, absorbance was measured in a spectrophotometer at a wavelength of $550 \mathrm{~nm}$. Absorbance of a sample was compared with that of standard sodium nitrite solutions.

\section{Identification of iNOS mRNA by RT-PCR}

Total RNA was isolated from PC12 cells using guanidinium isothiocyanate as described elsewhere (Chomczynski and Sacchi, 1987). First-strand cDNA was reverse-transcribed from 2 $\mu \mathrm{g}$ of total RNA in a total volume of $10 \mu \mathrm{l}$ with 200 units of Moloney murine leukemia virus reverse transcriptase (Gibco$\mathrm{BRL}$ ) at $37^{\circ} \mathrm{C}$ for $60 \mathrm{~min}$. PCR primers were designed based on the rat aortic endothelial iNOS cDNA sequence (Iwashina et al., 1996). The sense primer was 5'-AAA TCC AGA TAA GTG ACA- $3^{\prime}$, and the antisense primer was 5'-TGA ACG TCC AGG TTT AGA-3'. To test the efficacy of reverse transcription, RT-PCR was performed for $\beta$-actin mRNA. All PCR procedures were carried out in a total volume of $50 \mu \mathrm{l}$ containing $10 \mathrm{~m} M$ Tris- $\mathrm{HCl}(\mathrm{pH} 8.3), 50 \mathrm{~m} M \mathrm{KCl}, 200 \mu M$ each deoxynucleotide triphosphate, $1.5 \mathrm{mM} \mathrm{MgCl}$, and $1.25 \mathrm{U}$ of Taq polymerase (Perkin-Elmer) with the following PCR conditions: 30 cycles of $1 \mathrm{~min}$ at $94^{\circ} \mathrm{C}$ (denaturation), 2 min of $57^{\circ} \mathrm{C}$ (annealing), and $3 \mathrm{~min}$ of $72^{\circ} \mathrm{C}$ (extension).

\section{Western blot analysis with anti-ERK or -JNK1 antibody}

Cells were solubilized with lysis buffer A containing $20 \mathrm{mM}$ Tris (pH 7.9), $137 \mathrm{mM} \mathrm{NaCl}, 5 \mathrm{~m} M \mathrm{Na}_{2}$ EDTA, $10 \%$ glycerol, $1.0 \%$ Triton X-100, $0.2 \mathrm{~m} M$ phenylmethylsulfonyl fluoride, 1 $\mu \mathrm{g} / \mathrm{ml}$ aprotinin, $20 \mu M$ leupeptin, $1 \mathrm{~m} M \mathrm{Na}_{3} \mathrm{VO}_{4}, 1 \mathrm{~m} M$ EGTA, $10 \mathrm{~m} M \mathrm{NaF}, 1 \mathrm{~m} M$ tetrasodium pyrophosphate, and 1 $\mathrm{m} M \beta$-glycerophosphate. Then cell extracts were resolved by sodium dodecyl sulfate-polyacrylamide gel electrophoresis $(12.5 \%$ gel $)$ and transferred to a nitrocellulose membrane. After blocking, the membranes were incubated with an ERK2-specific monoclonal antibody (Santa Cruz) or JNK1-specific polyclonal antibody (Santa Cruz) according to the manufacturer's 


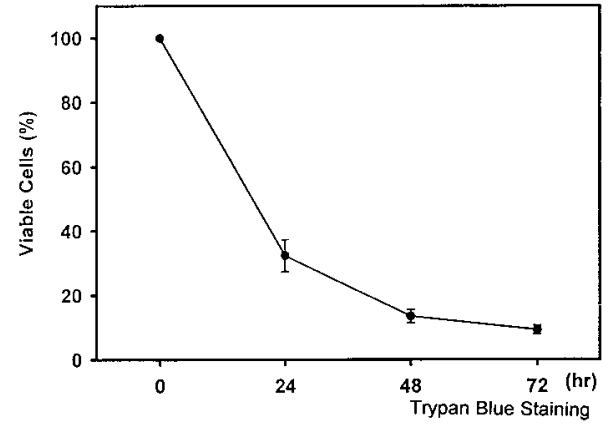

FIG. 1. Induction of cell death in PC12 cells by serum deprivation. PC12 cells were cultured for the indicated time in serumfree DMEM. The assay to measure cell viability was done by counting cells that exclude trypan blue as described in Experimental Procedures. Viability of the cells in regular-serum medium is defined as $100 \%$. Data are mean \pm SD (bars) values ( $n$ $=3)$.

protocol. The membrane was then incubated with a peroxidaseconjugated secondary antibody, and the bands were visualized by enhanced chemiluminescence (ECL; Amersham, Buckinghamshire, U.K.).

\section{Protein kinase assay for JNK and ERK}

Confluent cells were harvested and lysed using buffer A. Cell lysates were subjected to centrifugation at $12,000 \mathrm{~g}$ for 10 $\min$ at $4^{\circ} \mathrm{C}$. The soluble fraction was incubated for $1 \mathrm{~h}$ at $4^{\circ} \mathrm{C}$ with antibodies against JNK1 and ERK2. After addition of protein A-Sepharose beads (Pharmacia, Uppsala, Sweden), the reaction mixture was incubated for $1 \mathrm{~h}$ at $4^{\circ} \mathrm{C}$ and then rinsed with buffer A three times and $20 \mathrm{~m} M$ HEPES ( $\mathrm{pH}$ 7.4) two times. Immunocomplex kinase assays were performed by incubating the immunopellets for $30 \mathrm{~min}$ at $30^{\circ} \mathrm{C}$ with appropriate substrate proteins in the reaction buffer containing $0.2 \mathrm{mM}$ sodium orthovanadate, $2 \mathrm{~m} M$ dithiothreitol, $10 \mathrm{mM} \mathrm{MgCl}{ }_{2}, 2$ $\mu \mathrm{Ci}$ of $\left[\gamma_{-}{ }^{32} \mathrm{P}\right] \mathrm{ATP}$, and $20 \mathrm{~m} M$ HEPES, $\mathrm{pH}$ 7.4. The reaction was terminated by adding polyacrylamide gel electrophoresis sample loading buffer and heating the solution in boiling water for $3 \mathrm{~min}$. The reaction mixture was subjected to electrophoresis on a $12.5 \%$ acrylamide gel. The phosphorylated substrates were visualized by autoradiography. Myelin basic protein (Santa Cruz) and glutathione $S$-transferase (GST)-c-Jun (kindly provided by Dr. P. Angel) were used as the substrate for ERK and JNK, respectively. GST-c-Jun was prepared with a GST purification module (Pharmacia) according to the manufacturer's protocol.

\section{RESULTS}

\section{Serum deprivation of $\mathrm{PC12}$ cells triggered cell death}

When serum was removed from PC12 cells for up to $72 \mathrm{~h},<10 \%$ of the total cells survived, and within $24 \mathrm{~h}$ the relative cell viability was decreased by $65-70 \%$, as measured by the trypan blue staining method (Fig. 1). When we quantified LDH released from membrane-damaged PC12 cells to assess cell death, a similar level of cell death was observed after serum deprivation for $24 \mathrm{~h}$ (data not shown). In contrast, when regular serum including 5\% fetal bovine serum plus 5\% horse serum was present, LDH level measurements showed that percentage of cell death by $24 \mathrm{~h}$ was $<5 \%$ (data not shown). This value is in part due to the LDH originally present in the serum irrespective of cell membrane destruction.

\section{Differential generation of cytotoxic NO by serum deprivation plus TNF $\alpha$ or PMA}

When PMA in the range of $3-300 \mathrm{ng} / \mathrm{ml}$ was added to serum-deprived media, the cell death fraction was decreased in a dose-dependent manner, reaching a 50\% increase in cell viability at $300 \mathrm{ng} / \mathrm{ml}$ concentration (Fig. 2A). However, when $1-30 \mathrm{ng} / \mathrm{ml} \mathrm{TNF} \alpha$ was added to serum-deprived media, the relative amount of cell death in $\mathrm{PC} 12$ cells was increased by $60-70 \%$, compared with that of only serum-starved control cells (Fig. 2B).

To check the generation of reactive NO molecules during these treatments, we measured the formation of nitrite $\left(\mathrm{NO}_{2}{ }^{-}\right)$, a stable breakdown product of $\mathrm{NO}$ (Table 1). PC12 cells grown in regular 5\% horse serum and 5\% fetal bovine serum generated very little nitrite, close to a background level. In contrast, treatment of PC12 cells with serum-free DMEM caused persistent NO generation for $24 \mathrm{~h}$ that reached up to $\sim 2.0 \mathrm{nmol}$ per $10^{5}$ cells at $24 \mathrm{~h}$, indicating NO generated by serum deprivation has a cytotoxic effect on neuronal PC12 cells. When 30 $\mathrm{ng} / \mathrm{ml} \mathrm{TNF} \alpha$ was added in the serum-free medium for $24 \mathrm{~h}$, nitrite formation was increased by $\sim 55 \%$ compared
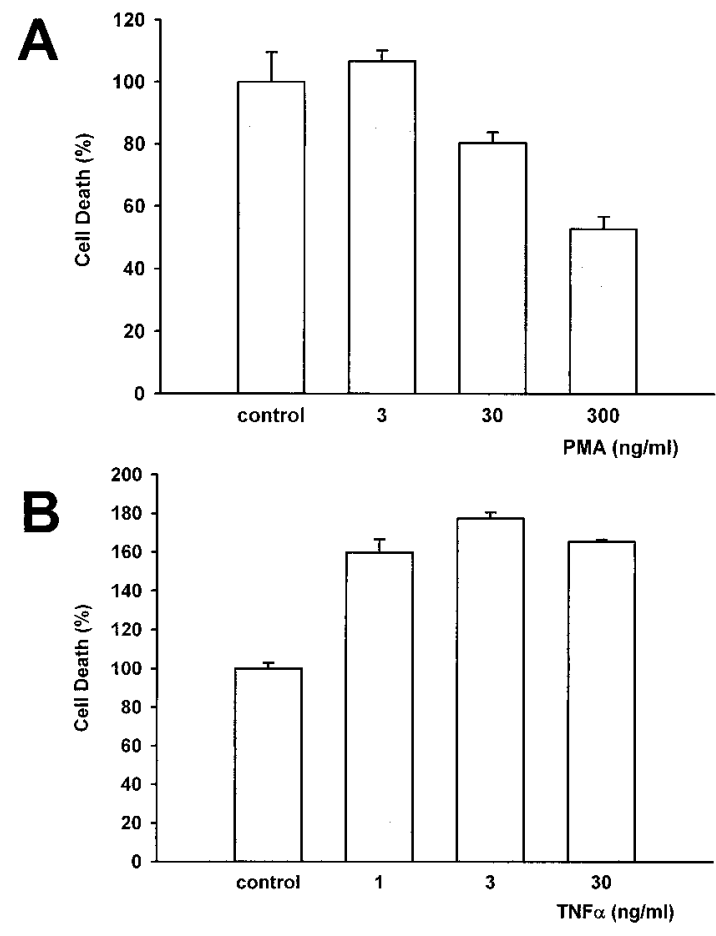

FIG. 2. Effect of addition of PMA or TNF $\alpha$ on serum-deprived cell death of PC12 cells. PC12 cells were cultured in serum-free medium for $24 \mathrm{~h}$ containing various concentrations of (A) PMA or (B) TNF $\alpha$. Cell death was measured by the LDH method as described in Experimental Procedures. The cell death of PC12 cells under serum-free medium for $24 \mathrm{~h}$ is defined as $100 \%$ (control). Data are mean \pm SD (bars) values $(n=3)$. 
TABLE 1. Generation of NO by serum deprivation in the absence or presence of PMA or TNF $\alpha$

\begin{tabular}{lc}
\hline \multicolumn{1}{c}{ Treatment } & Nitrite formation $\left(\mathrm{nmol} / 1 \times 10^{5}\right.$ cells $)$ \\
\hline Serum & $0.08 \pm 0.05$ \\
SD & $2.00 \pm 0.17$ \\
SD + PMA & $1.08 \pm 0.32$ \\
SD + TNF $\alpha$ & $3.09 \pm 0.06$ \\
\hline
\end{tabular}

PC12 cells were incubated in DMEM supplemented with 5\% heatinactivated fetal bovine serum and 5\% horse serum (Serum) or serumfree DMEM for $24 \mathrm{~h}$ in the absence (SD) or presence of $30 \mathrm{ng} / \mathrm{ml}$ $\mathrm{TNF} \alpha(\mathrm{SD}+\mathrm{TNF} \alpha)$ or $300 \mathrm{ng} / \mathrm{ml}$ PMA (SD + PMA). The amount of nitrite in the supernatant was determined using the Griess method as described in Experimental Procedures. Data are mean \pm SD values ( $=3)$.

with that of serum-deprived control cells. When 300 $\mathrm{ng} / \mathrm{ml}$ PMA was added in serum-free medium for $24 \mathrm{~h}$, NO formation was decreased to $\sim 46 \%$. These data suggest that differential cytotoxic NO formation by serum deprivation in the absence or presence of the cytokine $\mathrm{TNF} \alpha$ or the tumor promoter PMA is causing differential levels of cell death in neuronal PC12 cells.

Although treatment with PMA alone in regular serum medium did not produce any significant levels of nitrite and cell death, addition of TNF $\alpha$ to serum-containing medium caused similar levels of NO formation and cell death as in serum-deprived cells, suggesting that the effect of TNF $\alpha$ and serum deprivation might be additive (Table 2). When the iNOS-selective inhibitor aminoguanidine (AG) was added to serum-deprived media with $\mathrm{TNF} \alpha$, it partially blocked the cell death effect of serum deprivation plus TNF $\alpha$. We also observed that addition of AG significantly inhibited nitrite formation (Table 2), suggesting that $\mathrm{NO}$ formation by serum deprivation is primarily mediated by the iNOS enzyme activity. NO donors, such as sodium nitroprusside (SNP) and $S$-nitroso- $N$-acetylpenicillamine (SNAP), were added to serum-deprived media to examine the effect of $\mathrm{NO}$ on PC12 cell death induced by serum deprivation (Table 2). As expected, treatment with SNP or SNAP for $24 \mathrm{~h}$ increased nitrite formation $\sim 2$.4-fold and also increased the cell death effect by serum deprivation in a dosedependent manner, from 10 up to $100 \mu M$ concentration. These data clearly showed that NO generated from serum-deprived PC12 cells has a cytotoxic effect.

\section{Induction of apoptosis of PC12 cells with serum deprivation}

To distinguish whether differential NO formation in PC12 cells induced by serum deprivation in the absence or presence of TNF $\alpha$ or PMA caused cell death by a necrotic or apoptotic process, we performed experiments to measure the formation of DNA laddering and annexin $\mathrm{V}$ staining in PC12 cells after treatment with serum-free DMEM in the presence of $\mathrm{TNF} \alpha$. The induction of apoptosis by serum deprivation plus $\mathrm{TNF} \alpha$ was suggested by the internucleosomal degradation that gave rise to the DNA laddering pattern, characteristic of some apoptotic processes (Fig. 3A). In addition, we observed the appearance of a population of cells with increased annexin $\mathrm{V}$ binding, an indication of the exposure of negatively charged phospholipids to the outer surface of the plasma membrane (Fig. 3B). This cell population maintained a low (close to background) staining with propidium iodide, which is indicative of membrane integrity, and therefore represents early apoptotic cells. Relatively less formation of DNA laddering and annexin $\mathrm{V}$ staining in PC12 cells treated with serum deprivation alone or in the presence of PMA was also observed (data not shown).

\section{Mediation of NO synthesis by induced iNOS during serum deprivation}

To confirm that the iNOS enzyme is responsible for NO formation during the apoptotic process, we measured the induction of iNOS enzymes in PC12 cells under conditions of serum deprivation in the absence or presence of TNF $\alpha$ or PMA (Fig. 4). When we changed the serum-containing DMEM to serum-free medium, there was a significant induction of iNOS mRNA as identified by RT-PCR. When $30 \mathrm{ng} / \mathrm{ml} \mathrm{TNF} \alpha$ or $300 \mathrm{ng} / \mathrm{ml}$ PMA was added to serum-deprived media, there was an increase or a decrease of induced iNOS mRNA levels, respectively. The differential induction of iNOS mRNA levels correlates with the cell death or protection pattern observed on addition of these two agents to serumdeprived PC12 cells. This finding suggests that the formation of cytotoxic NO is primarily mediated by induction of the iNOS enzyme and that the differential cell

TABLE 2. Effect of NO donor and iNOS inhibitor on nitrite formation and cell death induced by serum deprivation in PC12 cells

\begin{tabular}{lcc}
\hline \multicolumn{1}{c}{ Treatment } & $\begin{array}{c}\text { Cell death } \\
(\%)\end{array}$ & $\begin{array}{c}\text { Nitrite formation } \\
\left(\mathrm{nmol} / 1 \times 10^{5} \text { cells }\right)\end{array}$ \\
\hline SD & 100 & $1.97 \pm 0.23$ \\
SD + TNF $\alpha$ & $159 \pm 3.0$ & $3.24 \pm 0.16$ \\
SD + TNF $\alpha$ & & \\
$\quad+$ AG $(10 \mu M)$ & $118 \pm 4.6$ & $2.13 \pm 0.08$ \\
+ AG $(100 \mu M)$ & $86 \pm 5.9$ & $1.46 \pm 0.12$ \\
SD & & \\
+ SNP $(10 \mu M)$ & $136 \pm 2.6$ & $2.86 \pm 0.25$ \\
+ SNP $(100 \mu M)$ & $218 \pm 13.8$ & $4.24 \pm 0.64$ \\
+ SNAP $(10 \mu M)$ & $125 \pm 8.5$ & $2.34 \pm 0.18$ \\
$\quad+$ SNAP $(100 \mu M)$ & $224 \pm 11.6$ & $4.39 \pm 0.47$ \\
TNF $\alpha(30 \mathrm{ng} / \mathrm{ml})$ & $89 \pm 11.4$ & $2.24 \pm 0.31$ \\
SNP $(100 \mu M)$ & $97 \pm 12.9$ & $2.42 \pm 0.45$ \\
SNAP $(100 \mu M)$ & $108 \pm 6.1$ & $1.86 \pm 0.39$ \\
PMA $(300 \mathrm{ng} / \mathrm{ml})$ & $15.4 \pm 1.2$ & $0.36 \pm 0.16$ \\
SNP + PMA & $46 \pm 8.2$ & $0.86 \pm 0.27$ \\
SNAP + PMA & $38 \pm 5.5$ & $1.14 \pm 0.12$ \\
\hline
\end{tabular}

After a 1-h addition of $30 \mathrm{ng} / \mathrm{ml}$ TNF $\alpha$ in serum-free medium, 10 or $100 \mu M$ iNOS inhibitor, AG, was added and incubated for $24 \mathrm{~h}$. The NO donors SNP and SNAP (10 or $100 \mu M$ ) were incubated in serumfree medium for $24 \mathrm{~h}$. To test the effect of TNF $\alpha$, SNP, SNAP, or PMA in regular serum media, each reagent was added to PC12 cells in medium containing DMEM with 5\% horse serum and 5\% fetal bovine serum for $24 \mathrm{~h}$, and cell death and nitrite formation were measured as described in Fig. 2 and Table 1. Data are mean \pm SD values $(n=3-4)$. 


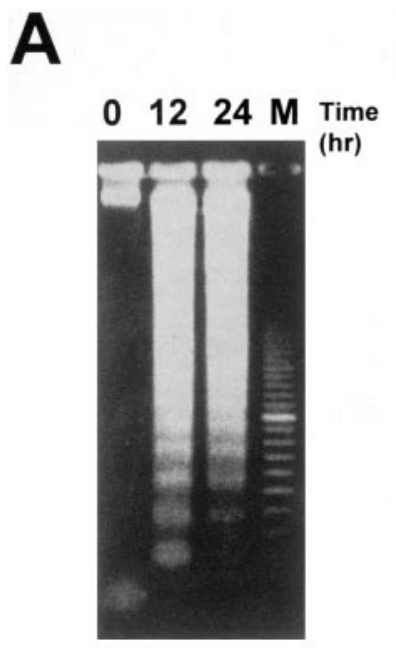

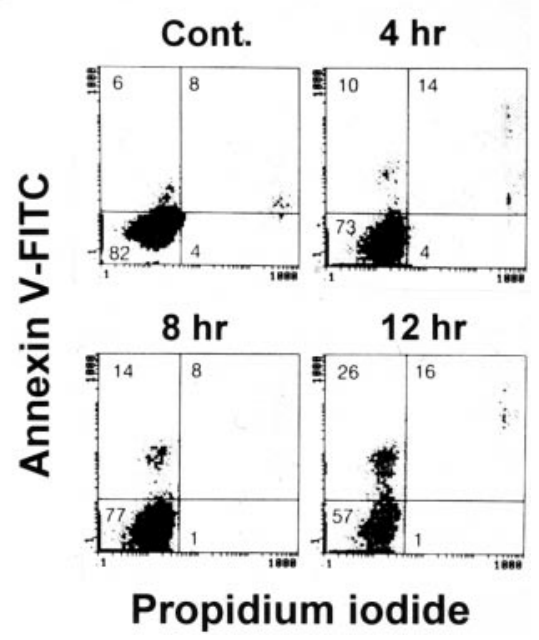

FIG. 3. Induction of apoptosis of PC12 cells treated with serum deprivation plus TNF $\alpha$. A: Effect of serum deprivation plus TNF $\alpha$ on the formation of DNA laddering. PC12 cells were cultured in the presence of $30 \mathrm{ng} / \mathrm{ml} \mathrm{TNF} \alpha$. After the indicated time, cells were harvested, and fragmented DNA was analyzed on agarose gels as described in Experimental Procedures. The marker lane (M) contains a 123-bp DNA ladder standard. B: Binding of annexin V-FITC to PC12 cells treated with TNF $\alpha$ in serum-deprived medium versus loss of plasma membrane integrity, as assessed by propidium iodide uptake. After the indicated treatment interval with $30 \mathrm{ng} / \mathrm{ml}$ TNF $\alpha$ serum-deprived medium, binding of annexin V-FITC and uptake of propidium iodide were assayed as described in Experimental Procedures. Insets: The proportion of cells within each quadrant. Results shown are representative of three independent experiments. Cont., control (no treatment). death effect of NO by $\mathrm{TNF} \alpha$ and the cell-protective effect of PMA in serum-deprived PC12 cells are mediated by the differential induction of iNOS enzymes.

\section{Cytotoxic NO stimulates JNK activity}

To clarify the downstream signaling cascades of cytotoxic NO generated by serum deprivation in the absence or presence of TNF $\alpha$ or PMA, we measured the activity of endogenous ERK and JNK by an in-gel kinase assay using myelin basic protein as the ERK substrate and GST-c-Jun as the JNK substrate. As shown in Fig. $5 \mathrm{~A}, \mathrm{JNK}$ activity is markedly increased after removal of serum from PC12 cells. Furthermore, addition of TNF $\alpha$ to serum-deprived media significantly increased JNK

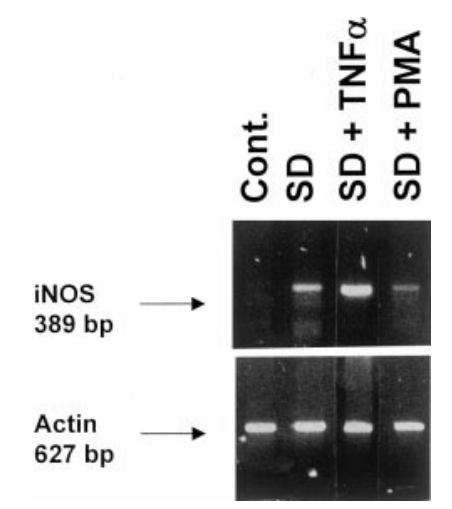

FIG. 4. Differential induction of iNOS mRNA levels by treatment in serum-deprived medium with PMA or TNF $\alpha$ in PC12 cells. RT-PCR analysis was performed on RNA isolated from cultured PC12 cells after no treatment (referred to Cont.) or following serum deprivation in the absence (SD) or presence of $30 \mathrm{ng} / \mathrm{ml}$ TNF $\alpha$ (SD + TNF $\alpha$ ) or $300 \mathrm{ng} / \mathrm{ml}$ PMA (SD + PMA) for $24 \mathrm{~h}$ at $37^{\circ} \mathrm{C}$. RT and PCR were carried out as described in Experimental Procedures. Top Panel: A 389-bp iNOS PCR product was detected. Bottom panel: A 627-bp $\beta$-actin fragment was detected by RT-PCR as a control for equal RNA loading. activity, whereas addition of PMA to serum-deprived media decreased JNK activity. The enhanced JNK activity induced by $\mathrm{TNF} \alpha$ in serum-deprived media was inhibited significantly by coaddition of the iNOS inhibitor AG (Fig. 5B), consistent with a role for JNK in cytotoxic NO-mediated apoptosis. Addition of TNF $\alpha$, SNP, or SNAP to the regular serum-containing medium also stimulated JNK1 activity compared with the control sample. As a control for protein loading, we measured the amount of nonactivated JNK1 enzyme using anti-JNK1 antibody. In all samples, JNK1 enzymes were present at the same levels. When we measured the activation of ERK using myelin basic protein as substrate, we did not observe any activation by serum deprivation or differential activation of ERK by addition of $\mathrm{TNF} \alpha$ or PMA, respectively (data not shown).

\section{DISCUSSION}

Recently many lines of evidence have implicated NO as a major synaptic signaling agent in the nervous system (Schmidt and Walter, 1994). Apart from this role under physiological conditions, NO plays a complex role in regulating cell viability. Depending on the NO concentration, necrosis or apoptosis could be induced by NO. NO production has been implicated in neuronal injury after ischemia and trauma and in numerous neurodegenerative disorders (Beckman, 1996; Nicotera et al., 1997). $\mathrm{NO}$ appears to mediate neuronal death when produced in excess. For instance, during cerebral ischemia, excessive glutamate release leads to overstimulation of NMDA receptors, which in turn causes $\mathrm{Ca}^{2+}$ influx and activation of the $\mathrm{Ca}^{2+}$-dependent NOS (Garthwaite, 1991). The mechanism by which excessive NO leads to neuronal cell death is unclear but could include direct activation or inhibition of signaling or metabolic pathways.

In contrast, NO has also been reported to be cytoprotective in certain circumstances. For instance, NO donors 


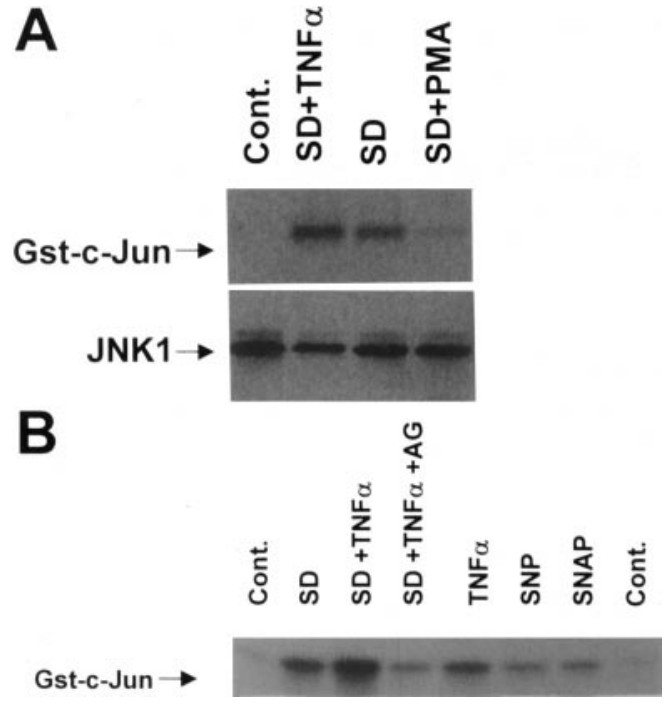

FIG. 5. Differential activation of JNK activities by serum deprivation plus PMA or TNF $\alpha$. A: Confluent PC12 cells were exposed to DMEM containing $5 \%$ fetal bovine serum and $5 \%$ horse serum (Cont.) or to serum-free medium in the absence (SD) or presence of $30 \mathrm{ng} / \mathrm{ml} \mathrm{TNF} \alpha$ (SD + TNF $\alpha$ ) or $300 \mathrm{ng} / \mathrm{ml} \mathrm{PMA} \mathrm{(SD}$ + PMA) for $24 \mathrm{~h}$ at $37^{\circ} \mathrm{C}$. Cells were harvested and lysed using buffer A. JNK1 was isolated by immunoprecipitation using antiJNK1 antibody, and the catalytic activities of JNK1 in the immunopellets were assayed for phosphorylation of GST-C-Jun as described in Experimental Procedures. As a control for equal protein loading, nonphosphorylated JNK1 levels were measured by western analysis as described in Experimental Procedures. The reaction mixtures were analyzed by polyacrylamide gel electrophoresis on a $12.5 \%$ polyacrylamide gel and by autoradiography. B: Activation of JNK by addition of an NO donor or TNF $\alpha$ and inhibition of serum deprivation-induced JNK activation by an iNOS inhibitor. PC12 cells were exposed to serum deprivation in the absence (SD) or presence of $30 \mathrm{ng} / \mathrm{ml} \mathrm{TNF} \alpha$ (SD + TNF $\alpha$ ) or plus $100 \mu M$ AG (SD + TNF $\alpha+A G)$. To test the effect of 30 $\mathrm{ng} / \mathrm{ml}$ TNF $\alpha, 100 \mu M$ SNP, or $100 \mu M$ SNAP, each reagent was added into PC12 cells containing regular serum DMEM, and JNK activity was measured after $24 \mathrm{~h}$.

and the NO precursor ( $\mathrm{L}$-arginine) are cytoprotective in a model of myocardial ischemia-reperfusion (Siegfried et al., 1992). Very recent studies have revealed that NO inhibits apoptosis of human B lymphocytes caused by Epstein-Barr virus reactivation (Mannick et al., 1994) as well as the death of cytokine-deprived human eosinophils (Beauvais et al., 1995). NO also had a protective role in damage caused by reactive oxygen species. Thus, it has been discussed that the NO effect on cell viability is dependent on its concentration, cellular redox state, cell types, and interacting cell regulatory mechanisms.

The dual effects of $\mathrm{NO}$ with regard to cytotoxicity and cytoprotection have led us to examine its actions in a well-characterized neuronal model, the rat pheochromocytoma PC12 cell line, in which cell death is initiated by withdrawal of trophic support. Previously, we reported that TNF $\alpha$ and PMA had a protective effect on cell death induced by serum deprivation in bovine endothelial cells and that this protection was related to NF- $\kappa \mathrm{B}$ activation (Ahn et al., 1996; Kim and Ahn, 1997). iNOS is one of the molecules for which transcription is regulated mainly by NF- $\kappa$ B. To verify the cytotoxic or cytoprotective effect of NO via the induction of iNOS and to elucidate its downstream signaling cascades such as the activation of MAP kinases, we investigated the effect of NO formation by serum deprivation in the absence or presence of TNF $\alpha$ or PMA in neuronal PC12 cells. In contrast to its cytoprotective role in endothelial cells, cytotoxic NO was generated in serum-deprived PC12 cells, and it promoted cell death. Both studies implied that the effect of $\mathrm{NO}$ on cell viability is largely dependent on the specific cell type.

Addition of TNF $\alpha$, which causes the stimulation of iNOS induction, potentiated PC12 cell death induced by serum deprivation. Increased expression of iNOS levels was confirmed by RT-PCR, and increased NO levels were measured indirectly by nitrite measurement. However, addition of the tumor promoter PMA decreased cell death induced by serum deprivation, and it caused less activation of iNOS and less production of NO, compared with that in serum-deprived control cells. This finding suggested that, in contrast to the cytokine TNF $\alpha$, the PMA-stimulated PKC pathway negatively regulates cytotoxic NO formation in serum-starved PC12 cells. Like NO, both cytoprotective and cytotoxic effects have been reported for TNF $\alpha$. The possibility is discussed that the role of $\mathrm{TNF} \alpha$ in cell viability is determined on the signaling pathway predominantly regulated by it and the type of cell used. Although many TNF $\alpha$-related receptor families and pathways have been elucidated, the effect of $\mathrm{TNF} \alpha$ on cell viability has not yet been clearly demonstrated.

The tumor promoter PMA was also shown to have a dual effect on cell death, causing increases as well as decreases in NO formation, iNOS induction, and NOmediated cell death, depending on the cell type. For example, apoptosis induced by the NO donor SNAP was prevented by the PKC inhibitors calphostin $\mathrm{C}$ and $\mathrm{H}-7$ and was potentiated by the PKC activator PMA in smooth muscle cells (Nishio and Watanabe, 1997). In mixed neuronal/glial cultures, activation of PKC by PMA increased lipopolysaccharide-induced NO and increased lipopolysaccharide-induced dopaminergic neurotoxicity (McMillian et al., 1997). This result indicated that NO donor-induced apoptosis is modulated by PKC. However, in vascular smooth muscle cells, PKC activation inhibits cytokine-induced NO synthesis (Geng et al., 1994). Also, PKC was shown to inhibit the activity of NOS in dispersed gastric muscle cells (Murthy et al., 1994).

When the selective iNOS inhibitor AG was used, the cytotoxic effect of TNF $\alpha$ was partially blocked, suggesting that iNOS expression is involved in the formation of $\mathrm{NO}$ and the control of NO-mediated cell death. Exogenously added NO donors (SNP and SNAP) also potentiated the cell death induced by serum deprivation. These results clearly showed that formation of NO can mediate cell death effects induced by serum deprivation in neuronal PC12 cells and that iNOS is one of the possible 
target molecules by which TNF $\alpha$ and PMA exert their cytotoxic or cytoprotective effects.

Knowing that iNOS is present ubiquitously in various cell types, much attention has recently been focused on the potential function of this highly reactive molecule. However, the regulatory effect of this molecule on cell function is still in question. In particular, the effect of iNOS on cell viability is quite controversial. Among the three NOS isoforms, endothelial NOS, neuronal NOS, and iNOS, only the activation of iNOS is regulated mainly at the transcriptional level. As NF- $\kappa$ B is known to have a crucial role in transcriptional regulation of iNOS (Xie et al., 1994), the NO-mediated cell death effect could be mediated by the activation of NF- $\kappa \mathrm{B}$ as an upstream target of iNOS induction.

The mechanism of NO-induced cell death is not clear, although DNA damage and activation of poly(ADPribose) synthase have been proposed as a mechanism for NO-induced neuronal death (Zhang et al., 1994). For the downstream signal transduction pathway of NO, it was recently shown that NO stimulates JNK activity through activation of JNK kinase in HEK293 cells (Kim et al., 1997). Our present study also showed that the differential formation of cytotoxic NO via iNOS induction by serum deprivation plus PMA or TNF $\alpha$ is associated with the activation of JNK but not ERK in neuronal PC12 cells. JNK plays a critical role in the regulation of cell death in various cell systems. The regulation of NO by the induction of iNOS may be important for better understanding the mechanism by which NO exerts diverse functions in normal physiological events and pathological states.

Acknowledgment: This work is supported by a 1997 Research Fund from Yonsei University (to K.C.C.). We thank Dr. P. Angel for kindly providing the GST-c-Jun expression plasmid and Dr. Marsha Rosner for critical reading of the manuscript. We also gratefully acknowledge the generous technical assistance by Drs. C. Park, S. Ryu, M. Choi, and B. Kim.

\section{REFERENCES}

Aggarwal B. B. and Natarajan K. (1996) Tumor necrosis factors; development during last decades. Eur. Cytokine Netw. 7, 93-124.

Ahn Y. S., Kim C. H., and Hsu C. Y. (1996) Protection of NF- $\kappa$ B against cerebral endothelial cell death induced by serum starvation. (Abstr.) Korean J. Pharmacol. 32 (Suppl.), 91.

Beauvais F., Michel L., and Dubertret L. (1995) The nitric oxide donors, azide and hydroxylamine, inhibit the programmed cell death of cytokine-deprived human eosinophils. FEBS Lett. 361, $229-232$.

Beckman J. S. (1996) The physiological and pathological chemistry of nitric oxide, in Nitric Oxide: Principles and Actions (Lancaster J. R., ed), pp. 1-82. Academic Press, San Diego.

Chomczynski P. and Sacchi N. (1987) Single-step method of RNA isolation by acid guanidinium thiocyanate-phenol-chloroform extraction. Anal. Biochem. 162, 156-159.

Coyle J. T. and Puttfarcken P. (1993) Oxidative stress, glutamate, and neurodegenerative disorders. Science 262, 689-695.

Dawson V. L., Dawson T. M., London E. D., Bredt D. S., and Snyder S. H. (1991) Nitric oxide mediates glutamate neurotoxicity in primary cortical cultures. Proc. Natl. Acad. Sci. USA 88, $6368-$ 6371.

Estrada G., Gomes C., Martin C., Moncada S., and Gonzales C. (1992) Nitric oxide mediates tumor necrosis factor- $\alpha$ cytotoxicity in endothelial cells. Biochem. Biophys. Res. Commun. 186, 475-482.

Follett M. J. and Ratcliff P. W. (1963) Determination of nitrite and nitrate in cured meat products. J. Chromatogr. 14, 138-144.

Garthwaite J. (1991) Glutamate, nitric oxide and cell-cell signaling in the nervous system. Trends Neurosci. 14, 60-67.

Geng Y. J., Wu Q., and Hansson G. K. (1994) Protein kinase C activation inhibits cytokine-induced nitric oxide synthesis in vascular smooth muscle cells. Biochim. Biophys. Acta 1223, 125132.

Iwashina M., Hirata Y., Imai T., Sato K., and Marumo F. (1996) Molecular cloning of endothelial and inducible nitric oxide synthase gene from rat aortic endothelial cell. Eur. J. Biochem. 237, $668-673$.

Kim C. H. and Ahn Y. S. (1997) Nitric oxide prevents the bovine cerebral endothelial cell death induced by serum-deprivation. Korean J. Physiol. Pharmacol. 1, 515-525.

Kim H., Shim J., Han P. L., and Choi E.-J. (1997) Nitric oxide modulates the c-Jun $\mathrm{N}$-terminal kinase/stress-activated protein kinase activity through activating c-Jun N-terminal kinase kinase. Biochemistry 36, 13677-13681.

Lo Y. Y. C., Wong J. M. S., and Cruz T. F. (1996) Reactive oxygen species mediate cytokine activation of c-Jun $\mathrm{NH}_{2}$-terminal kinases. J. Biol. Chem. 271, 15703-15707.

Mannick J. B., Asano K., Izumi K., Kieff E., and Stampler J. S. (1994) Nitric oxide produced by human B lymphocytes inhibits apoptosis and Epstein-Barr virus reactivation. Cell 79, 1137-1146.

McMillian M. K., Vainio P. J., and Tuominen R. K. (1997) Role of protein kinase $\mathrm{C}$ in microglia-induced neurotoxicity in mesencephalic cultures. J. Neuropathol. Exp. Neurol. 56, 301-307.

Murthy K. S., Jin J. G., and Makhlouf G. M. (1994) Inhibition of nitric oxide synthase activity in dispersed gastric muscle cells by protein kinase C. Am. J. Physiol. 266, G161-G165.

Nicotera P., Brune B., and Bagetta G. (1997) Nitric oxide: inducer or suppressor of apoptosis. Trends Pharmacol. Sci. 18, 189-190.

Nishio E. and Watanabe Y. (1997) Nitric oxide-induced apoptosis in smooth muscle cells is modulated by protein kinase $\mathrm{C}$ and protein kinase A. Eur. J. Pharmacol. 339, 245-251.

Okada D. (1996) Differential effects of protein kinase C on neuronal nitric oxide synthase activity in rat cerebellar slices and in vitro. J. Chem. Neuroanat. 10, 213-220.

Oppenheim R. W. (1991) Cell death during development of the nervous system. Annu. Rev. Neurosci. 14, 453-501.

Robinson M. J. and Cobb M. H. (1997) Mitogen-activated protein kinase pathways. Curr. Opin. Cell Biol. 9, 180-186.

Rukenstein A., Rydel R. E., and Greene L. A. (1991) Multiple agents rescue PC12 cells from serum-free cell death by translation- and transcription-independent mechanisms. J. Neurosci. 11, 25522563.

Schmidt H. H. H. W. and Walter U. (1994) NO at work. Cell 78, 919-925.

Siegfried M. R., Erhardt J., Rider T., Ma X., and Lefer A. M. (1991) Cardioprotection and attenuation of endothelial dysfunction by organic nitric oxide donors in myocardial ischemia-reperfusion. J. Pharmacol. Exp. Ther. 260, 668-675.

Wallach D. (1997) Cell death induction by TNF: a matter of self control. Trends Biochem. Sci. 22, 107-109.

Wyllie A. H. (1993) Apoptosis (1992 Frank Rose Memorial Lecture). Br. J. Cancer 67, 205-208.

Xie Q. W., Kashiwabara Y., and Nathan C. (1994) Role of transcription of NF- $\kappa \mathrm{B} / \mathrm{Rel}$ induction of nitric oxide synthase. J. Biol. Chem. 269, 4705-4708.

Zhang J., Dawson V. L., Dawson T. M., and Snyder S. H. (1994) Nitric oxide activation of poly(ADP-ribose) synthethase in neurotoxicity. Science 263, 687-689. 